\title{
Proses Kolaboratif dalam Perencanaan Berbasis Komunikasi pada Masyarakat Nonkolaboratif
}

\author{
ELY SUFIANTI, ${ }^{1}$ DEWI SAWITRI ${ }^{2}$ KRISHNAI NUR PRIBADI, ${ }^{3}$ TOMMY FIRMAN ${ }^{4}$ \\ 1 Mahasiswa Prodi Perencanaan Wilayah dan Kota, Sekolah Arsitektur, Perencanaan, dan Pengembangan \\ Kebijakan, Institut Teknologi Bandung \\ 2, 3, 4 Dosen Prodi Perencanaan Wilayah dan Kota, Institut Teknologi Bandung \\ email: ${ }^{1}$ esufianti@yahoo.com
}

\begin{abstract}
The collaborative process is a key element of the communicative-based planning. This process requires participations, equality of power, as well as adequate competence of the actors who engage the process. This condition seems difficult to occur in the societies, especially those in developing countries, in which people's participation, equality of power, and competence are considered low (uncollaborative society). The purpose of this paper is to explore whether the collaborative process can occur or not in the context of such societies. The empirical investigation was conducted by using the qualitative research methods with a case study approach to sidewalk vendors arrangement planning at Banjarsari, Surakarta City. It shows that the planning involves the collaborative process stages and authentic dialogue, which are the key aspects of collaborative process
\end{abstract}

Keywords: collaboration, planning, sidewalk vendors

\begin{abstract}
Abstrak. Proses kolaboratif merupakan unsur utama dari perencanaan berbasis komunikasi. Proses kolaboratif memerlukan partisipasi, kesetaraan kekuasaan, serta kompetensi yang memadai dari para pemangku kepentingan. Kondisi ini terlihat sulit terjadi pada masyarakat yang cenderung memiliki tingkat partisipasi, kesetaraan kekuasaan, dan kompetensi rendah (masyarakat nonkolaboratif), suatu kondisi masyarakat yang masih terjadi terutama di negara-negara berkembang. Tujuan artikel ini adalah untuk melihat secara mendalam apakah proses kolaboratif dapat terjadi pada konteks masyarakat demikian. Hal ini dilihat melalui penelitian empiris dengan kasus perencanaan penataan pedagang kaki lima Banjarsari di Kota Surakarta, dengan menggunakan metode kualitatif. Hasil penelitian memerlihatkan bahwa pada perencanaan tersebut terdapat tahapan-tahapan proses kolaboratif dan dialog otentik yang merupakan aspek utama dalam proses kolaboratif.
\end{abstract}

Kata kunci: kolaboratif, perencanaan, pedagang kaki lima

\section{Pendahuluan}

Dalam tataran praktik, pentingnya ruang kolaborasi dalam pembangunan dihadapi oleh permasalahan pedagang kaki lima (PKL) dalam kaitannya dengan penataan ruang kota. Selama ini PKL menduduki ruang publik dan mengakibatkan kekumuhan dan kemacetan lalu lintas. Dalam menyelesaikan masalah tersebut, seringkali terjadi keributan antara pemerintah dan PKL. Pemerintah melakukannya dengan alasan penataan kota, sementara PKL merasa hak mereka untuk berpenghasilan dirampas begitu saja. Mereka menganggap pemerintah hanya mengusir tanpa memikirkan nasib mereka. Dengan demikian, dalam menyelesaikan masalah ini, diperlukan keterlibatan intensif kedua belah pihak, yaitu pemerintah dan PKL. Kedua belah pihak perlu duduk bersama.

Kasus tersebut merupakan salah satu contoh yang memerlihatkan bahwa proses pembangunan saat ini tidak lagi hanya menjadi dominasi pemerintah. Kritik bahwa pembangunan hanya menjadi kepentingan pihak tertentu, menyadarkan pemerintah akan perlunya komunikasi dan tindakan bersama dengan para pemangku kepentingan. Hal ini menimbulkan munculnya pemikiran collaborative governance (Anshell \& Gash, 2007; Innes \& Booher, 2010), dimana para pemangku kepentingan duduk bersama untuk mengambil suatu keputusan publik yang merupakan hasil konsensus melalui suatu proses dialog tatap muka.

Sebagai bagian dari proses pembangunan 
yang telah mengalami pergeseran paradigma, perencanaan juga mengalami pergeseran paradigma ke arah perencanaan berbasis komunikasi yang menjadi salah satu unsur penting dalam pembangunan berbasis kolaborasi, seperti dijelaskan dalam Gambar 1. Pada awalnya, perencanaan berlandaskan pada rasionalitas instrumental, yang dikenal sebagai rational planning (Banfield, 1959). Namun pendekatan ini seringkali mengabaikan realitas politik, sehingga Charles Lindbloom (1959) mengajukan gagasan tentang disjointed incementalism dan Amitai Ezioni (1967) dengan gagasan Mixed-scanning. Meskipun terdapat perubahan pendekatan, namun perencanaan tetap hanya melibatkan para pemikir dan pengambil keputusan. Di lain pihak, diyakini bahwa perencanaan juga harus memikirkan kepentingan semua kelompok masyarakat sehingga kaum marjinal pun harus terwakili dalam perencanaan. Dalam situasi ini, perencana perlu berperan sebagai seorang advokat, innovator, dan birokrat (Davidoff, 1965; Dyckman, 1961, Beckman, 1964). Berikutnya, Friedman (1973) mengemukakan pemikiran tentang perencanaan transaktif dimana perencanaan seyogyanya disusun berdasarkan dialog antara perencana dengan klien-nya. Friedman (1987, dalam Friedman 2011) juga mengemukakan bahwa perencanaan dalam tataran publik, dimana bahwa perencanaan merupakan suatu bentuk aplikasi atas pengetahuan ke dalam tindakan dan mengelompokkan perencanaan sebagai Social Reform, Policy Analysis, Social Learning, dan Social Mobilization. Perubahan pendekatan ini menjadikan perencanaan tidak hanya milik pemerintah, tetapi milik masyarakat.

\section{Proses Kolaboratif sebagai Unsur Utama Perencanaan Berbasis Komunikasi}

Beberapa pendekatan perencanaan, yaitu perencanaan transaktif (Friedman, 1973), perencanaan kolaboratif (Healey, 1996), perencanaan komunikatif (Sager, 1994; Innes, 1997), perencanaan deliberatif partisipatif (Forester, 2000), dan perencanaan konsensus (Woltjer, 2000), memiliki karakteristik yang relatif sama dalam hal menekankan pentingnya kerjasama dengan didasari komunikasi antarpemangku kepentingan. Proses kerjasama tersebut akan berlangsung dengan baik jika terdapat komunikasi dalam bentuk dialog didalamnya. Dalam perencanaan transaktif, dialog yang terjadi adalah life dialogue, yang dipertegas oleh Innes dan Booher (1997) sebagai authentic dialogue. Dalam hal ini, setiap aktor yang duduk bersama saling menghargai, empati, terjadi hubungan timbal balik dan saling menguntungkan. Dengan demikian, dialog hanya akan terjadi jika para pemangku kepentingan berpartisipasi dan duduk bersama dalam memecahkan permasalahan. Partisipasi sendiri hanya akan terjadi jika mereka memiliki kepentingan dan memiliki kesempatan untuk menyuarakan kepentingannya, dan partisipasi tersebut hanya akan terjadi jika ada saling ketergantungan dan kepercayaan. Kerjasama melalui dialog dan partisipasi diarahkan pada pembentukan konsensus (Woltjer, 2000; Innes, 1996). Proses yang memuat aktivitas dialog, partisipasi, dan berorientasi kepada keputusan bersama, terangkum dalam suatu proses kolaboratif. Dengan demikian, dalam suatu pendekatan perencanaan berbasis komunikasi,

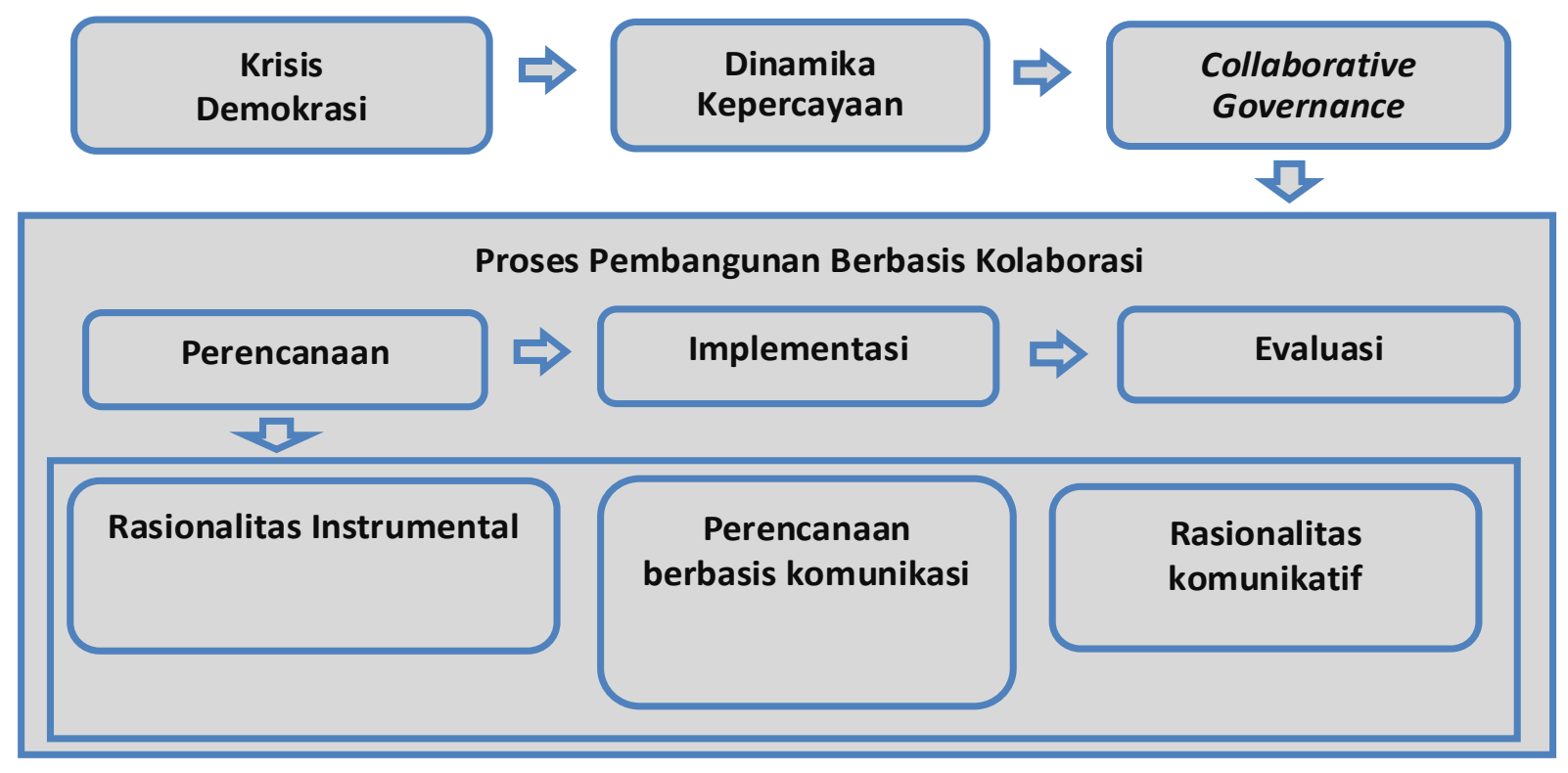

Gambar 1

Proses Pembangunan Berbasis Kolaborasi dan Pergeseran Paradigma Perencanaan 
terjadi proses kolaboratif (Gambar Perencanaan kolaboratif (Healey, 1997; Innes, 1998).

Proses kolaboratif merupakan suatu proses adaptive system dimana pendapat-pendapat yang berbeda dari berbagai pihak yang akhirnya menghasilkan suatu konsensus. Anshell dan Gash (2008) berupaya memetakan suatu model yang menggambarkan bagaimana proses kolaboratif terjadi. Proses kolaboratif menurut model ini terdiri dari berbagai tahapan yaitu dimulai dari adanya dialog secara tatap muka (face-to-face dialogue), membangun kepercayaan (trust building), membangun komitmen terhadap proses (commitment to the process), berbagi pemahaman (shared understanding), dan kemudian terbentuknya hasil sementara (intermediate outcome). Tahapan ini merupakan suatu siklus sehingga terjadi proses pembelajaran didalamnya. Innes dan Booher (2010) mengembangkan model DIAD Network Dynamic untuk memerlihatkan bahwa proses kolaborasi menggambarkan jejaring kolaboratif dimana terdapat keragaman, saling ketergantungan dan dialog otentik didalamnya. Hal ini berarti bahwa: pertama, jejaring kolaboratif memiliki keragaman agen-agen, kedua, agen-agen berada dalam situasi mampu untuk saling memenuhi kepentingan masing-masing dan menyadari adanya saling ketergantungan diantara mereka, dan ketiga, terdapat dialog otentik (authentic dialogue) dimana komunikasi mengalir melalui jejaring secara akurat dan dapat dipercaya diantara para peserta. Dalam dialog otentik, terdapat timbal balik (reciprocity), hubungan (relationship), pembelajaran (learning), kreatifitas (creativity), dan menghasilkan adaptasi dari sistem yang ada. Hal ini berarti bahwa para peserta (aktor) berbicara mewakili kepentingan kelompoknya, saling menghormati, dan berbicara dengan akurat. Tentu saja hal ini membutuhkan kepercayaan, komitmen, dan pemahaman diantara para aktor.

\section{Permasalahan: Kesenjangan Pra-syarat Proses Kolaboratif}

Dengan memerhatikan bagaimana proses kolaboratif dalam perencanaan terjadi, dimana terjadi dialog otentik yang berorientasi konsensus didalamnya, maka dapat dikatakan bahwa proses kolaboratif terjadi jika terdapat beberapa prasyarat (Sufianti, 2013). Prasyarat tersebut adalah: (1) Terdapat partisipasi para pemangku kepentingan (Anshel dan Gash, 2008; Healey, 2006; Woltjer, 2000). Partisipasi yang sebenarnya adalah citizen power seperti dikekukakan dalam tangga partisipasi menurut Arnstein (1969). Pada umumnya, tingkat partisipasi tinggi muncul dalam masyarakat yang sudah menjalankan sistem demokrasi. (2) Terdapat kondisi dimana ada kesetaraan kekuasan (Anshell dan Gash, 2008;

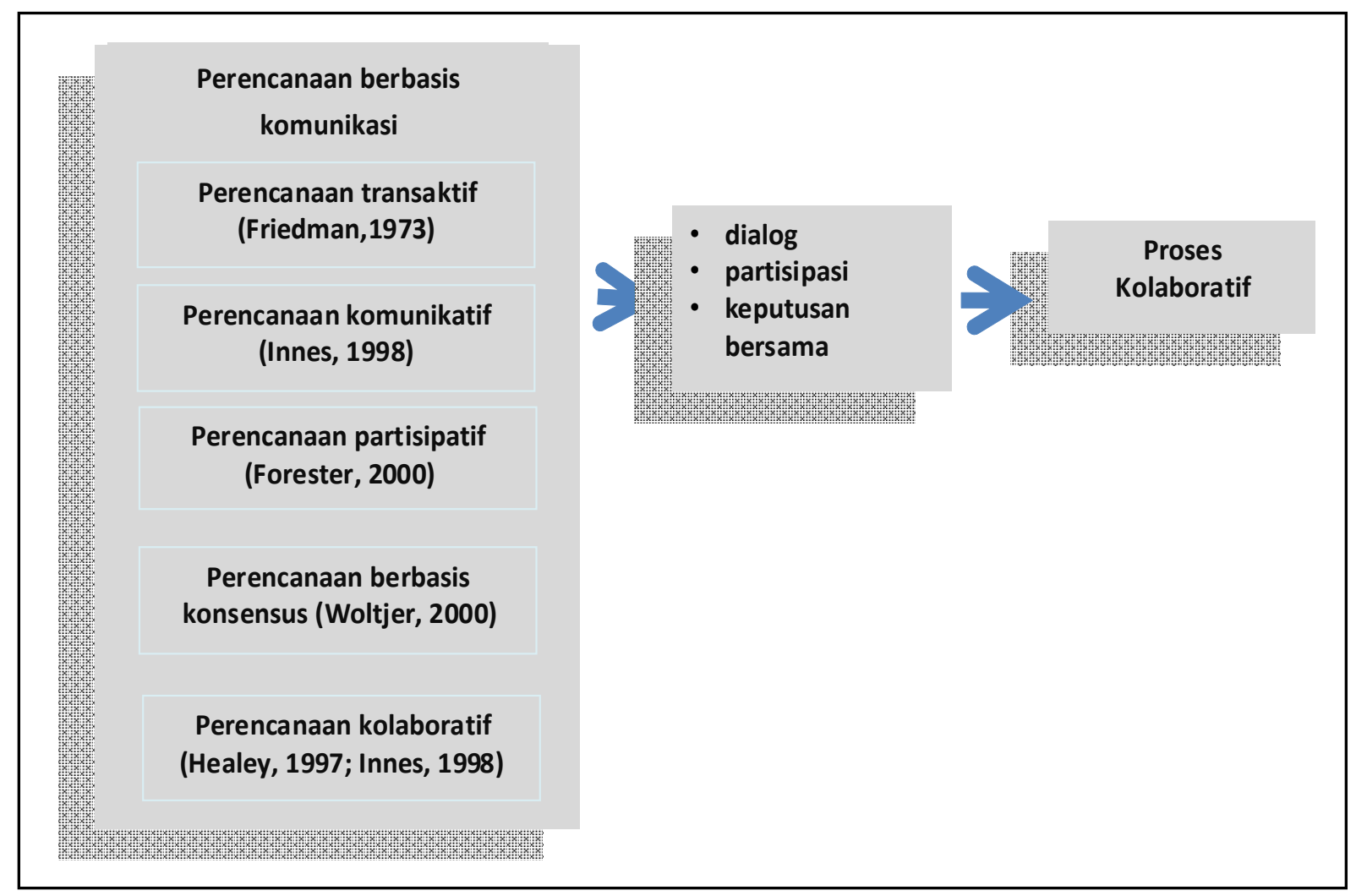

Gambar 2

Kedudukan Proses Kolaborasi dalam Perencanaan Berbasis Komunikasi. 
Healey, 2008; Innes dan Booher, 2000). Hal ini berarti tidak ada dominasi oleh pihak tertentu, setiap aktor yang berdialog tidak dihalangi oleh batas hirarki, dan terdapat rasa saling menghormati. (3) Terdapat aktor-aktor yang kompeten. Dialog yang terjadi harus merupakan bentuk komunikasi yang berorientasi konsensus, sehingga memerlukan aktor yang mendukung, dalam arti memiliki kompetensi dalam berkomunikasi, memahami substansi, dan memiliki orientasi mencapai tujuan untuk kepentingan bersama. Pentingnya peran aktor yang memeliliki kemauan dan kompetensi dinyatakan oleh de Roo dalam Actor Consulting Model (2007).

Prasyarat seperti pada Gambar 3, memperlihatkan bahwa proses kolaboratif akan dapat berjalan dengan baik dengan partisipasi aktif masyarakatnya diwakili oleh aktor-aktor yang memiliki kemampuan berdialog. Hal ini hanya dapat terjadi di negara-negara maju dan sudah demokratik. Dengan melihat prasyarat di atas, maka proses kolaboratif tidak dapat dengan mudah terwujud pada masyarakat yang memiliki tingkat partisipasi masyarakat yang rendah, serta kepemimpinan yang tidak mendukung. Kondisi seperti ini masih mudah dijumpai pada masyarakat tertentu, umumnya di negara-negara berkembang.
Hal ini umumnya terjadi karena berkaitan dengan masalah budaya dan tingkat pendidikan masyarakatnya. Partisipasi masyarakat dalam mengikuti proses perencanaan pembangunan masih terdapat banyak kelemahan terutama melalui jalur musrenbang (Akadun, 2011), dan konsep pembangunan yang partisipatif perlu dirumuskan dalam suatu strategi yang menyeluruh (Djoeffan, 2002). Dalam hal ini, masyarakat Surakarta yang berlatar belakang budaya Jawa, digunakan sebagai kasus masyarakat yang secara umum berada dalam kondisi yang tidak memenuhi prasyarat terjadinya proses kolaboratif, dengan tingkat partisipasi rendah, kompetensi rendah, dan kesetaraan kekuasaan rendah. Adapun karakteristik masyarakat Surakarta dari sisi tingkat partisipasi, kompetensi, dan kesetaraan kekuasaan, dapat dilihat pada tabel 1 . Sedangkan Permasalahan dapat dilihat dalam gambar 3. Dari gambar tersebut terlihat adanya kesenjangan antara kondisi yang menjadi prasyarat tercapainya keberhasilan proses kolaboratif dengan kondisi nyata.

Berdasarkan latar belakang dan isu di atas, yang menjadi permasalahan adalah bagaimana proses kolaboratif pada masyarakat yang memiliki kesetaraan kekuasaan, tingkat partisipasi, dan

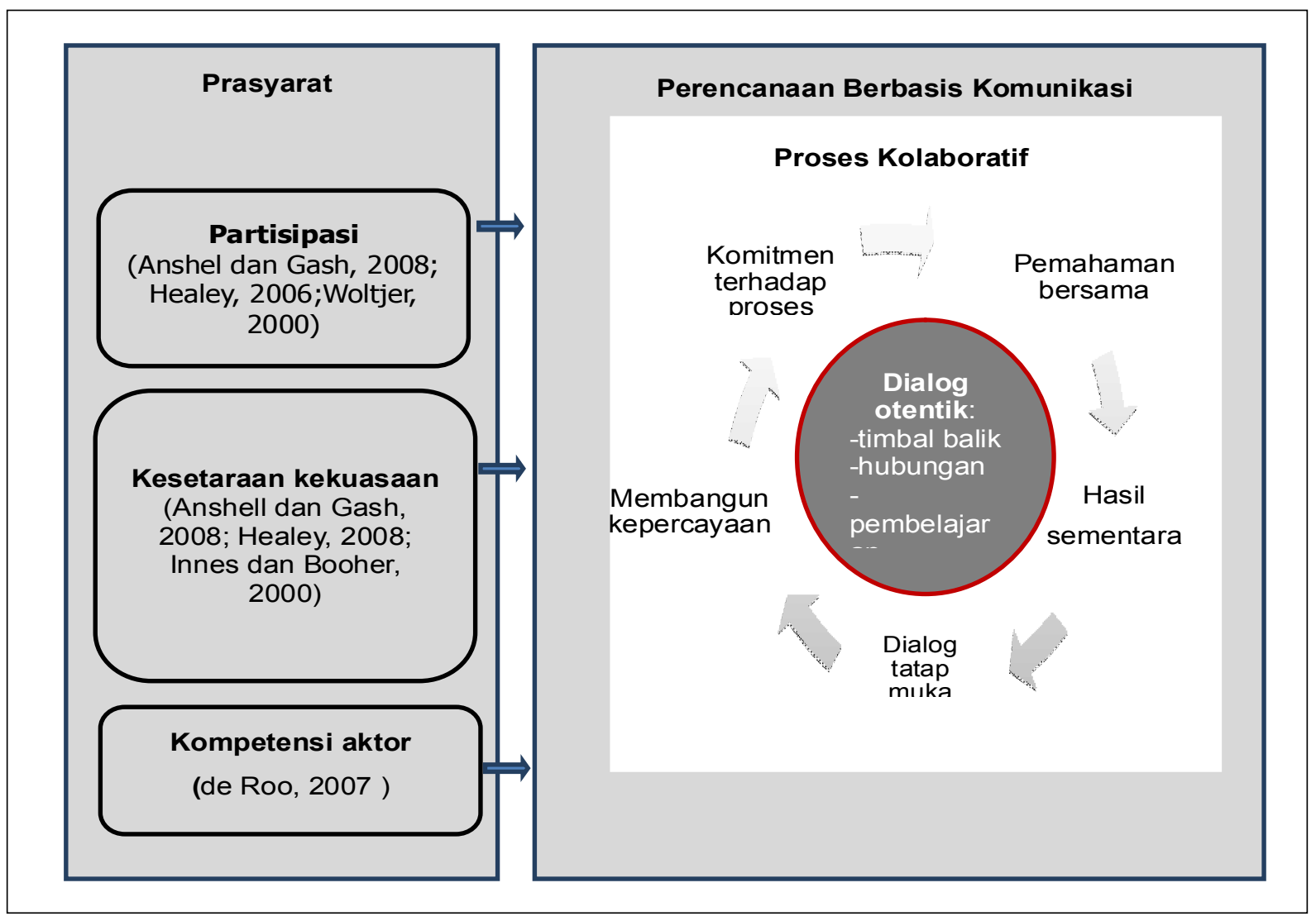

Gambar 3

Prasyarat Keberhasilan Proses Kolaboratif dan Proses Kolaboratif

(sumber: diadaptasi dari Ansell \& Gash, 2008; Innes \& Booher, 2000) 
Tabel 1. Karakteristik Masyarakat Surakarta dari Sisi Tingkat Partisipasi, Kompetensi, dan Kesetaraan Kekuasaan

\begin{tabular}{||l|l|l|}
\hline $\begin{array}{c}\text { Tingkat partisipasi } \\
\text { masyarakat relatif } \\
\text { rendah }\end{array}$ & $\begin{array}{c}\text { Kompetensi masyarakat } \\
\text { umumnya rendah }\end{array}$ & $\begin{array}{c}\text { Adanya ketidaksetaraan } \\
\text { kekuasaan }\end{array}$ \\
\hline $\begin{array}{l}\text { Awalnya rendah, mulai } \\
\text { meningkat setelah tahun } \\
2001^{*}\end{array}$ & $\begin{array}{l}\text { Persentase penduduk yang } \\
\text { tidak sekolah, belum tamat SD, } \\
\text { tidak tamat SD, dan tamat SD } \\
\text { yaitu } 45.26 \%(2011)^{* *}\end{array}$ & $\begin{array}{l}\text { Adanya latar belakang } \\
\text { feodalisme }\end{array}$ \\
\hline
\end{tabular}

* Kenyataan tentang rendahnya partisipasi masyarakat di Kota Surakarta sebelum 2001 terlihat setelah adanya upaya peningkatan partisipasi masyarakat yang terlihat keberhasilannya. Partisipasi masyarakat dalam pembangunan meningkat setelah mengadopsi pendekatan partisipasi pada tahun 2001 melalui bantuan LogoLink international network for participatory planning (Sugiartoto dalam Widianingsih, 2005)

** Surakarta dalam angka (2011)

kompetensi rendah? Dengan melihat kasus perencanaan penataan PKL Banjarsari, maka tujuan penulisan artikel ini adalah untuk menjelaskan bagaimana proses kolaboratif pada perencanaan penataan PKL Banjarsari di Kota Surakarta, serta memberikan gambaran kontribusi pemikiran yang dapat diberikan terhadap teori perencanaan berbasis komunikasi khususnya berkaitan dengan proses kolaboratif berdasarkan data empirik. Untuk mendapatkan jawaban atas permasalahan, digunakan penelitian dengan metode kualitatif dengan pendekatan studi kasus deskriptif (Creswell, 1998; Yin, 2009) dan studi kasus instrumental (Denzin dan Lincoln, 2009).
Pengumpulan data dilakukan terhadap data primer dan sekunder.

Teknik pengumpulan data primer dilakukan dengan wawancara terstruktur dengan menggunakan pertanyaan terbuka serta observasi sederhana (Denzin dan Lincoln, 2009). Wawancara dilakukan terhadap para aktor yang pernah terlibat dalam proses perencanaan penataan PKL Banjarsari tersebut. Adapun data sekunder yang dikumpulkan adalah peraturanperaturan terkait, soft file dari surat kabar lokal, foto-foto serta dokumen-dokumen resmi yang pernah diterbitkan oleh Kantor PPKL untuk melakukan wawancara dan pengamatan,

\begin{tabular}{|c|c|c|c|c|c|}
\hline \multicolumn{2}{|c|}{ Partisi pasi } & \multicolumn{2}{|c|}{ Kesetaraan Kekuasaan } & \multicolumn{2}{|c|}{ Kompetensi } \\
\hline Kondisi ideal & $\begin{array}{l}\text { Kondisi } \\
\text { nyate }\end{array}$ & Kondisi ideal & $\begin{array}{l}\text { Kondisi } \\
\text { nyata }\end{array}$ & Kondisi ideal & $\begin{array}{l}\text { Kondisi } \\
\text { nyata }\end{array}$ \\
\hline $\begin{array}{c}\text { Proses } \\
\text { kolaboratif } \\
\text { melibatkan } \\
\text { para } \\
\text { pemangku } \\
\text { kepentingan } \\
\text { sehingga } \\
\text { tingkat } \\
\text { partisipasi } \\
\text { diharapkan } \\
\text { tinggi }\end{array}$ & $\begin{array}{l}\text { Partisipasi } \\
\text { masih } \\
\text { rendah, } \\
\text { masih } \\
\text { sebatas } \\
\text { kehadiran }\end{array}$ & $\begin{array}{c}\text { Para aktor } \\
\text { dalam proses } \\
\text { kolaboratif } \\
\text { memiliki } \\
\text { kesempatan } \\
\text { sama dalam } \\
\text { mengemukaka } \\
\text { n pendapat, } \\
\text { saling } \\
\text { menghargai, } \\
\text { informasi } \\
\text { terbagi }\end{array}$ & $\begin{array}{c}\text { Dipengaruhi } \\
\text { feodalisme, } \\
\text { adanya } \\
\text { dominasi } \\
\text { pihak/ } \\
\text { kelompok } \\
\text { tertentu }\end{array}$ & $\begin{array}{c}\text { Para aktor } \\
\text { kompeten } \\
\text { untuk } \\
\text { melakukan } \\
\text { komunikasi } \\
\text { dan } \\
\text { menguasai } \\
\text { substansi }\end{array}$ & $\begin{array}{l}\text { Masyarakat } \\
\text { umumnya } \\
\text { memiliki } \\
\text { tingkat } \\
\text { kompetensi } \\
\text { rendah } \\
\text { dilihat dari } \\
\text { tingkat } \\
\text { pendidikan }\end{array}$ \\
\hline
\end{tabular}

Gambar 4

Permasalahan: Kesenjangan Prasyarat Proses Kolaboratif 
digunakan alat yaitu panduan wawancara, panduan observasi, alat perekam, catatan, dan kamera. Strategi untuk menganalisis data yang telah dikumpulkan, adalah dengan bersandarkan pada propisisi teoritis dan menggunakan deskripsi kasus. Data dan informasi kemudian dicocokan dengan model kerangka teoritik yang dikembangkan dari teori/konsep yang relevan (analisis pattern matching, Yin, 2009). Kerangka teoritik tersebut dijelaskan pada gambar 3.

\section{Deskripsi Proses Penataan Pedagang Kaki Lima (PKL) Banjarsari}

Secara umum, tahapan proses Penataan PKL Monumen Banjarsari '45 dapat digambarkan sebagai berikut:

\section{Persiapan: Pra Proses Kolaboratif}

Dalam penataan PKL Banjarsari, pemerintah menginisiasi perencanaan dengan mengidentifikasi bahwa permasalahan PKL merupakan masalah yang sangat penting dalam penataan kota. Dalam hal ini, identifikasi masalah dilakukan selain dengan memelajari kegagalan pemerintahan terdahulu, juga dengan memerhatikan kebutuhan penataan kota serta tuntutan masyarakat umum serta kebutuhan dari PKL itu sendiri. Dengan demikian identifikasi masalah pun dilakukan dengan melihat masalah dari sudut pandang para pemangku kepentingan. Selanjutnya, pemerintah kota mendata para pemangku kepentingan yang dapat mempengaruhi keberhasilan mengatasi permasalahan penataan tersebut, terutama para PKL. Hal tersebut sesuai dengan penuturan mantan Kepala Kantor Pengelolaan PKL, Kepala Dinas Pengelolaan Pasar yang juga mantan Kepala Satpol PP, dan seorang staf Satpol PP serta Subagyo (2007).

Persiapan dilakukan melalui pendataan dan pertemuan-pertemuan untuk mendapatkan dukungan politik, anggaran, dan formulasi strategi dengan pihak DPRD Kota Surakarta. Pendataan dilakukan dengan dikoordinasikan oleh Kantor Pengelolaan PKL. Menurut seorang staf Satpol PP, pendataan dilakukan dengan mendatangi tiap kios, dilakukan pada bulan September 2005. Adapun hasil pendataan saat itu memerlihakan adanya 989 pedagang yang tergabung dalam 10 Paguyuban di lokasi tersebut, dan terdiri dari 18 jenis barang dagangan (Subagyo, 2007).

Selama proses pendataan, terjadi keresahan dalam diri para pedagang. Mereka menolak dipindahkan karena menganggap bahwa apa yang akan dilakukan pemerintah saat itu tidak akan berbeda dengan sebelumnya. Mereka bereaksi dengan melakukan konsolidasi untuk memerkuat penolakan mereka. Dengan melakukannya secara door to door, mereka pada akhirnya sepakat untuk menolak. Salah seorang ketua paguyuban pada saat itu mengatakan: "Ketika itu, kami melakukan pertemuan terbuka di lapangan, diikuti oleh hampir setengah dari pedagang yang ada, dengan kesepakatan menolak pemindahan...".

Bersamaan dengan proses pendataan, jajaran pejabat Kota Surakarta melakukan pendekatan kepada masyarakat secara informal. Salah satu PKL mengatakan: "..Akhirnya malammalam pakai celana pendek, pak Jokowi tiba-tiba menyambangi kita naik motor, ya ngobrol-ngobrol atau malah bawa gorengan dan dia pergi lagi. Pernah juga malah gak pakai helm, pakai celana pendek, kaos, gak kelihatan kalau walikota." Pendekatan secara informal lebih dapat menggali keluhan dan keinginan para PKL. Hal yang sama juga dilakukan oleh wakil walikota dan kepala kantor PPKL.

\section{Pelaksanaan: Membangun Komunikasi dengan Para Pemangku Kepentingan}

Untuk mewujudkan rencana relokasi, pemerintah kota terus menerus melakukan upaya untuk melibatkan kepada para pemangku kepentingan. Terdapat dua pemangku kepentingan utama dalam perencanaan penataan PKL Banjarsari, yaitu pemerintah dan PKL. Dari pihak pemerintah, didalamnya terlibat hampir seluruh Satuan Kerja Perangka Daerah (SKPD) dalam Pemerintah Kota Surakarta. Selain itu, pihak yang satu suara ingin menata PKL Banjarsari adalah masyarakat, yang diwakili oleh tokoh-tokohnya. Dari pihak PKL, terdapat Lembaga Swadaya Masyarakat (Sompis, Leskap, Patiro, Yapi, Forkot) yang menyuarakan dan memerkuat posisi PKL. Selain itu, pihak perguruan tinggi (UNS) terlibat untuk mendukung keberhasilan program penataan PKL dengan meningkatkan kualitas PKL. Paguyuban PKL yang terlibat ada 9 paguyuban dan terlibat juga para PKL non paguyuban. Tokoh masyarakat yang terlibat diantaranya Ketua LPMK (Lembaga Pemberdayaan Masyarakat Kota) Kedung Lumbu, Ketua LPMK Pasar Semanggi, dan Budayawan.

Pendekatan secara formal dilakukan melalui konsultasi publik. Konsultasi publik yang diinisiasi oleh walikota, mengundang paguyuban-paguyuban yang menaungi PKL Banjarsari, terdiri dari 10 paguyuban. Dalam kartu undangan yang ditandatangani oleh Walikota, tertulis perihal Silaturahmi. Terdapat sambutan yang luar biasa terhadap undangan walikota, dimana dari pihak $\mathrm{PKL}$, yang menghadiri pertemuan lebih banyak dari yang diundang.

Aktivitas yang dilakukan adalah pada pertemuan-pertemuan awal dengan walikota hanya berupa silaturahmi, makan, mendengarkan hiburan cokekan (semacam keroncong), penjelasan kondisi kota, persoalan-persoalan kota, 
dan ada pembicaraan mengenai harapan-harapan ke depan tanpa melakukan pembicaraan mengenai relokasi, lalu pulang. Karena belum ada pembicaraan mengenai relokasi, waktu itu belum ada reaksi dari PKL.

Pertemuan tersebut berlanjut dengan pertemuan-pertemuan lain baik di Balai Kota, rumah dinas walikota maupun Kantor PPKL. Waktu pertemuan dilakukan bisa pagi, siang atau malam hari. Berlangsung selama 4-6 bulan. Yang memimpin pertemuan kadang walikota, wakil walikota, atau Kepala Kantor PPKL. Sekitar pertemuan ke 5, 6, 7 ada reaksi mulai ada respon penolakan. Setelah mengetahui akan dipindah, para PKL menolak dan menginginkan tetap ditata di sekitar Monumen Banjarsari, dengan alasan lahan masih luas. Tanggal 29 Desember 2005, PKL Banjarsari melakukan pertemuan dengan walikota untuk menyampaikan sikap penolakan. Tetapi dalam pertemuan tersebut, ada perubahan sikap pengurus karena walikota memberikan sosialisasi yang menjelaskan secara detail konsep dalam relokasi tersebut. Beberapa pengurus mulai menerima untuk direlokasi.

Tanggal 30 Desember 2005, walikota mengundang seluruh PKL Banjarsari (1000 orang) ke loji Gandrung untuk memberikan sosialisasi terhadap wacana relokasi sekaligus rencana sarana dan prasarana yang disiapkan pemkot di lokasi baru. Tawaran untuk memeroleh kios secara gratis beserta fasilitasnya (pengurusan SIUP gratis, kemudahan akses modal dari bank, pinjaman bergulir) merubah pandangan sebagian besar anggota PKL Banjarsari. Ada 3 paguyuban yang terang-terang menerima rencana tersebut. Kemudian melalui pertemuan berikutnya, memertimbangkan respon PKL untuk direlokasi pengurus PKL Banjarsari memutuskan untuk menerima relokasi karena sebagian besar tuntutan mereka kepada pemkot diluluskan.

Pada pertemuan (kurang-lebih) ke 15, untuk lebih mengefektifkan berjalannya konsultasi publik tersebut, maka dibentuk perwakilan dari masingmasing kelompok. Masing-masing kelompok memberikan tuntutan, diantaranya: minta trayek minibus antarkota, jalan dilebarkan, promosi, publikasi, bantuan modal koperasi, jaminan tidak ada PKL disana, kios gratis, bebas retribusi selama 6 bulan, perijinan gratis, sampai pada tuntutan jaminan bila pindah pasti laris (tidak kehilangan pembeli), serta jaminan hidup dan minta dikirab pada waktu pindah (pindah dikawal seluruh pejabat, mereka ingin pindah secara terhormat). Tuntutan dari masing-masing kelompok yang awalnya puluhan tersebut, kemudian diperas, dan kemudian semuanya dipenuhi oleh Walikota. Seperti dikatakan oleh salah seorang pegawai Satpol PP saat itu, bahwa respon Walikota Jokowi adalah,"... semua dijyakan, tak satupun ditolak, karena mereka berpikiran mau pindah aja sudah luar biasa artinya pemerintah tidak hanya profit oriented namun empowering, pemberdayaan...". Dari sekian tuntutan yang dicukupi adalah: trayek minibus antarkota, jalan dilebarkan, promosi (mengiklankan Pasar Klitikan yang khusus dibangun untuk relokasi selama empat bulan di televisi dan media cetak lokal), bantuan modal koperasi (lima juta rupiah per PKL), jaminan tidak ada PKL disana, kios gratis, surat ijin gratis, bebas retribusi selama 6 bulan.

\section{Analisis Proses Kolaboratif Perencanaan Penataan Pedagang Kaki Lima Banjarsari di Surakarta}

Berdasarkan kenyataan di atas, berikut ini adalah analisis terhadap proses yang terjadi pada waktu perencanaan relokasi PKL dari kawasan Banjarsari ke lokasi Semanggi, dengan menggunakan sudut pandang konsep proses kolaboratif dalam kerangka teori perencanaan berbasis komunikasi. Dari deskripsi proses penataan PKL Banjarsari, jika dikaitkan dengan proses kolaboratif menurut (Anshel dan Gash, 2007; Innes \& Boofer, 2000) terdapat rangkaian proses sebagai berikut: (1) Mengidentifikasi permasalahan; (2) Mengidentifikasi pemangku kepentingan; (3) Membangun kepercayaan, (4) Membangun pemahaman bersama; (5) Menghasilkan upaya pemecahan masalah bersama; dan (6) Membangun komitmen bersama. Dua tahap pertama merupakan tahapan pra-proses kolaboratif, sedangkan empat tahap berikutnya merupakan bagian dari proses kolaboratif. Hal ini sesuai dengan definisi dari proses kolaboratif yaitu suatu proses yang membawa para pemangku kepentingan baik publik maupun swasta, ke dalam suatu forum bersama lembaga publik, untuk terlibat dalam pembuatan keputusan berorientasi konsensus (Anshel dan Gash, 2007). Empat tahap berikutnya merupakan proses kolaboratif.

Proses kolaboratif merupakan upaya membangun komunikasi dengan para pemangku kepentingan. Para pemangku kepentingan adalah bagian dari suatu komunitas sosial dalam permasalahan tersebut yang memerlukan pengakuan terhadap keberadaannya. Para PKL sebagai bagian utama yang akan terkena dampak adalah pemangku kepentingan utama. Mereka adalah agen dalam teori Strukturasi Giddens, bagian dari dualitas struktur, yang mampu melakukan praktik-praktik sosial secara berulang dan berkesinambungan. Komunikasi yang dilakukan antara pemerintah dengan para $\mathrm{PKL}$ sejalan dengan paradigma teori komunikasi, yang tidak lagi memahami subjektivitas sebagai subjek yang terisolasi, sebaliknya memahami subjektivitas dan ilmu pengetahuan sebagai hasil proses-proses 
komunikasi intersubjektif. Pengetahuan adalah hasil konsensus dengan subjek lain. Hal ini merupakan konsep rasio komunikatif menurut Habermas.

Ada empat langkah utama yang dilakukan dalam proses perencanaan penataan PKL Banjarsari, yaitu membangun kepercayaan, membangun pemahaman bersama, menyusun upaya pemecahan bersama, dan membangun komitmen bersama. Keempat langkah tersebut dilakukan dalam suatu dialog tatap muka. Antara para pejabat pemerintah dengan PKL dan para pemangku kepentingan lainnya.

Jika dilihat lebih dalam, langkah-langkah proses tersebut "dijiwai" oleh hasil dari dialog otentik seperti dikemukakan oleh Innes dan Booher (2000) dalam DIAD Network theory, yaitu:

adanya timbal balik, hubungan, pembelajaran, dan adaptasi terhadap sistem. Misalnya dalam membangun kepercayaan, didalamnya terdapat unsur-unsur timbal balik, dalam membangun pemahaman bersama didalamnya terdapat unsurunsur hubungan, di dalam menyusun upaya pemecahan bersama muncul unsur pembelajaran termasuk kreativitas, dan dalam membangun komitmen bersama muncul unsur-unsur adaptasi terhadap sistem.

\section{Membangun Kepercayaan melalui Upaya Membangun Hubungan}

Para PKL tidak mau dipindahkan karena mereka tidak percaya jika pemerintah memiliki kepedulian terhadap nasib mereka. Berkaca dari masalah tersebut, maka pemerintah berupaya untuk mendapatkan kepercayaan masyarakat. Tidak hanya saling percaya antara masyarakat dan pemerintah, tetapi juga saling percaya diantara seluruh pemangku kepentingan. Mengakui kepedulian dan pengalaman yang mereka bagikan bersama, saling memahami, membangun empati, membangun hubungan profesional yang baru, saling menghargai, dan tidak saling berprasangka.

Terpenuhinya kriteria di atas terlihat dari hal-hal berikut: Pihak pemerintah dan PKL merupaya membangun empati, dengan berusaha merasakan ketika berada pada posisi di pihak lain. Pemerintah berupaya membangun mindset bahwa "PKL sahabat Pemkot", bukan musuh yang hendak dimusnahkan. Upaya ini terlihat pada saat awal pertemuan di Loji Gandrung, tidak ada pernyataan dari pihak pemerintah mengenai relokasi, karena pemerintah memahami bahwa para PKL menolak relokasi. Pihak pemerintah menjelaskan rencana relokasi setelah saling mengenal PKL melalui beberapa kali undangan makan bersama. Terjadi upaya saling menghargai dan tidak berprasangka dalam proses ini. Upaya menghargai misalnya terjadi pada saat pendataan PKL. Selama pendataan pihak pemerintah melalui petugas Kantor PPKL dan dukungan Satpol PP memerlakukan para PKL sebagai rekan. Bahkan para pemangku kepentingan saling mendukung satu sama lain, tidak saling menjatuhkan.

\section{Membangun Pemahaman Bersama melalui Timbal Balik}

Upaya membangun hubungan dilakukan dengan hubungan timbal balik diantara para pemangku kepentingan, yang berarti adanya saling memberi dan menerima diantara mereka. Hal ini terlihat dalam hal, ketika proses konsultasi publik, perwakilan dari pemerintah memfasilitasi terjadinya diskusi dengan para perwakilan paguyuban PKL. Mereka memerhatikan apa yang diusulkan oleh para PKL, terbukti dengan disetujuinya beberapa hal yang disampaikan oleh PKL. Selain itu, Organisasi kemasyarakatan memberikan bantuan pendampingan kepada para PKL baik saat dialog berlangsung maupun di luar dialog. SOMPIS mendampingi PKL utuk menyuarakan penolakan terhadap relokasi dan menyiapkan strategi yang akan dilakukan jika upaya penolakan gagal. Serangkaian pertemuan sebanyak enam kali dilakukan untuk tetap mengawal rencana penolakan sekaligus untuk konsolidasi di basis delapan paguyuban (Handayani, 2006). Hal lainnya adalah ketika para PKL sudah menyepakati untuk pindah, perwakilan perguruan tinggi menjadi fasilitator dalam pengundian kios yang akan ditempati, karena mereka dianggap netral. Setelah itu, mereka memberikan pelatihan kepada para PKL yaitu pelatihan manajemen bisnis. Terjadi upaya saling menghargai dan tidak berprasangka dalam proses ini, yaitu ditandai dengan para PKL mau menghadiri undangan dari pemerintah, terbukti dari kehadiran sekitar 150 orang, padahal yang diundang hanya 50 orang.

\section{Menyusun Upaya Pemecahan Bersama melalui Proses Pembelajaran dan Kreativitas}

Dalam proses perencanaan terdapat upaya untuk memecahkan permasalahan secara bersama, melalui suatu proses pembelajaran diantara para pemangku kepentingan. Didalamnya terdapat: (a) pembelajaran, interaksi, diskusi berkaitan dengan kepentingan, masalah, strategi yang paling mungkin; (b) melakukan brainstorming, membangun skenario; (c) saling melengkapi satu sama lain mengajak peserta tidak hanya berpikir out of the box untuk memecahkan masalah, tetapi juga membuat mereka tidak ragu mengeluarkan ide-ide yang dirasa belum matang; (d) dan pembentukan kreativitas.

Dalam proses perencanaan relokasi para PKL di Banjarsari, proses pembelajaran terjadi secara formal maupun informal. Secara formal terjadi pada saat penguatan kapasitas yang diberikan oleh LSM, serta oleh pemerintah kota. 
Proses pembelajaran secara formal oleh LSM SOMPIS terjadi pada saat (1) pelatihan pengembangan ekonomi produktif yang diselenggarakan pada tanggal 6-7 Maret 2006 di Wisma Subud Tawangmangu; (2) advokasi Kebijakan terhadap beberapa paguyuban PKL (Handayani, 2006).

Proses pembelajaran informal terjadi pada saat konsultasi publik di Loji Gandrung dan Kantor $P P K L$, yang dicirikan oleh adanya perubahan pemikiran dari penolakan terhadap rencana relokasi menjadi menyetujui rencana relokasi, yang disebabkan adanya kejelasan alasan dan rencana yang rinci serta konsekuensi yang akan diterima oleh para PKL jika mereka mau pindah. Disana terjadi diskusi antara pihak pemerintah dan para perwakilan PKL.

Para aktor yang terlibat dalam proses perencanaan berusaha untuk saling belajar. Diantaranya, terlihat dari cara mereka menyadari keterbatasan yang dimiliki masing-masing pihak, yaitu: ketika pemerintah menawarkan pemindahan ke lokasi tertentu (karena lokasi itulah yang paling memungkinkan secara tata ruang kota dan terdapat kemungkinan pengembangan yang baik), para PKL menyetujui dengan mengajukan persyaratan tertentu yang cukup banyak. Untuk lebih mengefektifkan proses pengajuan usulan dari para $\mathrm{PKL}$, pemerintah mengelompokkan perwakilan PKL yang hadir, dan kemudian tiap kelompok mengerucutkan persyaratan tersebut.

Selain itu, proses pembelajaran juga terjadi pada saat terjadi interaksi antara pejabat pemerintah kota dengan para $\mathrm{PKL}$ di tempat mereka berdagang. Para pejabat tersebut mendatangi PKL untuk melakukan pendekatan secara informal, menjadikan mereka sebagai teman, bukan sebagai "musuh" yang perlu "dihilangkan" keberadannya. Proses ini menjadikan para pejabat dan PKL semakin saling mengenal dan PKL menjadi menyadari bahwa mereka dihargai, dan pejabat kota menyadari bahwa PKL adalah bagian dari kota yang tidak akan disingkirkan keberadaannya.

Proses perencanan yang terjadi juga mengajak peserta berpikir kreatif, dalam arti tidak hanya berpikir out of the box untuk memecahkan masalah, tetapi juga membuat mereka tidak ragu mengeluarkan ide-ide yang dirasa belum matang. Dalam proses perencanaan relokasi PKL di Banjarsari, kepemimpinan yang ada berhasil memancing para PKL untuk berdiskusi memecahkan masalah yang ada. PKL yang hadir dalam pertemuan tidak ragu untuk mengajukan ide-ide berkaitan dengan tempat baru yang akan mereka tempati. Mereka mengajukan ide untuk mengantar kepergian PKL ke tempat baru melalui kirab (yang pada akhirnya oleh pihak pemerintah kota dikemas menjadi bentuk kirab budaya), serta memberi masukan dalam hal desain bangunan seperti penempatan letak tangga, serta warna cat bangunan (penuturan seorang mantan staf Satpol PP).

\section{Membangun Komitmen Bersama melalui Proses Adaptasi}

Melalui proses di atas, kemudian dihasilkan komitmen bersama terhadap proses untuk memecahkan masalah PKL melalui penataan. Hal ini dicirikan dengan adanya pemaknaan bersama terhadap permasalahan yang dihadapi, identitas bersama, adanya perubahan perilaku baru sebagai hasil pembelajaran, serta munculnya ide-ide kreatif yang ditemukan dalam dialog untuk kemudian menjadi praktik.

Proses adaptasi dapat dilihat dari adanya perubahan. Pada awalnya, mereka berpandangan bahwa mereka tidak membutuhkan taman, yang membutuhkan taman adalah orang kaya; yang mereka butuhkan adalah mereka dapat berjualan dan mendapatkan keuntungan untuk kelangsungan hidup keluarga mereka. Namun setelah melakukan dialog, mereka mau memahami bahwa kawasan Banjarsari bukanlah tempat yang diperuntukan untuk mereka berdagang, berdagang di sana adalah melanggar hukum, dan mau dipindahkan dengan mengajukan persyaratan tertentu kepada pemerintah kota. Sebaliknya, pihak pemerintah kota yang sebelumnya belum memahami sepenuhnya apa yang diinginkan oleh para PKL sehingga mereka tidak mau pindah, pada akhirnya memahami apa yang diinginkan oleh mereka dan bersedia memenuhi permintaan para PKL. Kedua belah pihak pada akhirnya memaknai secara sama permasalahan yang dihadapi.

Setelah saling memahami permasalahan yang dihadapi, maka para PKL dan pemerintah kota menyadari bahwa mereka berada dalam posisi yang sama, harus bersama-sama untuk memecahkan permasalahan penataan Banjarsari. Pemerintah sebagai inisiator melakukan pendekatan yang dapat menggugah nurani masyarakat untuk mau bekerja sama. Mereka yang pada awalnya menolak, pada akhirnya berkomitmen sepakat untuk melaksanakan. Dialog yang dilakukan telah mampu mengembangkan sikap dan perilaku baru, dimana para PKL mau mendengarkan dan mau mencari kemanfaatan bersama dari upaya penataan PKL kawasan Banjarsari tersebut. Terjadi perubahan pandangan/sikap dari yang tadinya menentang menjadi menyetujui, meskipun ada yang merasa awalnya terpaksa.

Ide-ide yang muncul dari para PKL mampu diwujudkan oleh pemerintah kota, baik dalam hal promosi, kepemilikan kios gratis, bahkan sampai kirab budaya yang telah menarik perhatian banyak 


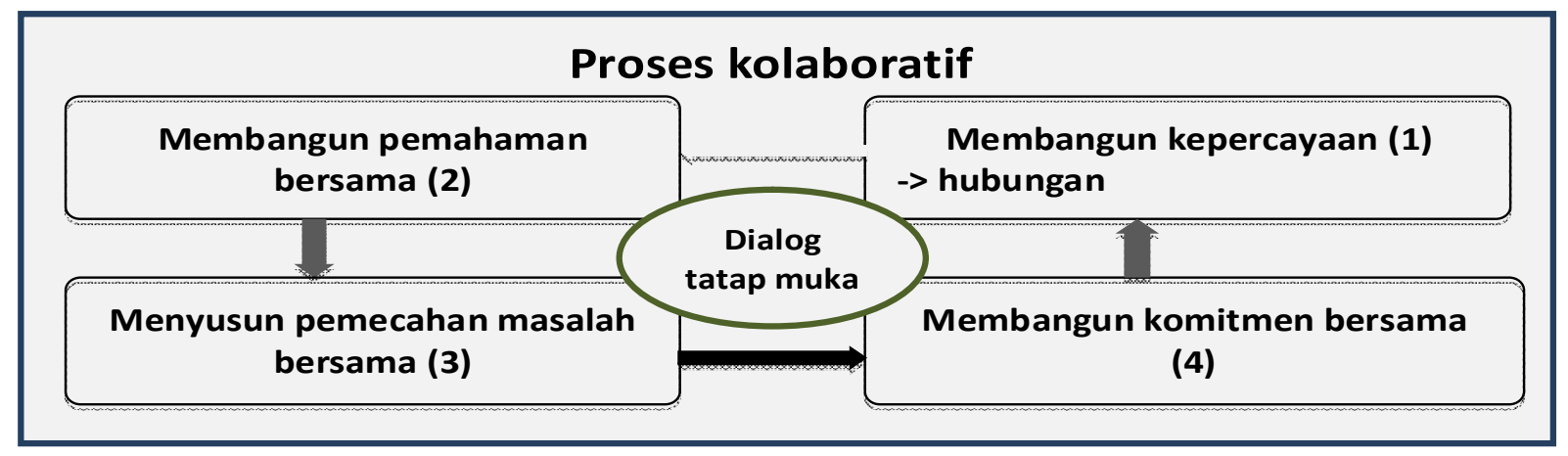

Gambar 5

Proses Kolaboratif terjadi melalui dialog tatap muka dengan dijiwai hasil dialog otentik

pihak. Ide-ide tersebut hampir semuanya diakomodir oleh pemerintah kota.

Dari penjelasan di atas, terlihat bahwa proses kolaboratifpada perencanaan penataan PKL Banjarsari telah terjadi. Dengan demikian meskipun masyarakat berada pada kondisi tingkat partisipasi, kompetensi, dan kesetaraan kekuasaan rendah, namun proses kolaboratif berjalan.

Proses kolaboratif yang terjadi adalah proses yang terjadi melalui dialog tatap muka dan dijiwai oleh hasil dialog otentik seperti yang dikemukakan oleh Innes dan Booher. Dialog tatap muka tidak menjadi bagian dari tahapan proses kolaboratif, tetapi dialog tatap muka terjadi dalam setiap tahapan yang dilalui (Gambar 5). Hal inilah yang membedakan hasil penelitian ini dengan model proses kolaboratif Collaborative Governance Model yang dikemukakan oleh Ansell dan Gash (2007).

\section{Simpulan dan Saran}

Proses kolaboratif merupakan bagian tak terpisahkan dari perencanaan berbasis komunikasi, yang terdiri dari beberapa tahap dan terdapat dialog otentik didalamnya. Proses ini memerlukan partisipasi tinggi, kesetaraan kekuasaaan, dan para aktor yang kompeten. Kondisi ideal ini terlihat sulit terjadi pada masyarakat yang memiliki tingkat partisipasi rendah, ketidaksetaraan kekuasaan, dan kompetensi yang redah. Namun hasil penelitian ini memerlihatkan bahwa proses kolaboratif telah terjadi pada masyarakat dengan tingkat partisipasi rendah, adanya ketidaksetaraan kekuasaan, kompetensi rendah. Proses ini dimulai dengan membangun kepercayaan melalui hubungan, membangun pemahaman bersama melalui timbal balik, memecahkan masalah melalui pembelajaran, dan membangun komitmen untuk mengimplementasikan pemecahan masalah melalui adaptasi terhadap sistem. Serangkaian tahapan tersebut terjadi melalui suatu proses dialog tatap muka. Dengan demikian, dialog tatap muka bukan merupakan bagian dari tahapan, tetapi terjadi pada semua tahapan. Artikel ini juga menemukan bahwa proses kolaboratif dapat terjadi pada masyarakat demikian karena adanya peran kepemimpinan. Kepemimpinan tersebut mampu memotivasi dan membawa mereka ke dalam proses kolaboratif, membuat mereka terlibat aktif, meningkatkan tingkat partisipasi, serta meningkatkan kemampuan komunikasi dan substansi dengan cara memotivasi mereka untuk membicarakan apa yang mereka butuhkan.

Kontribusi penelitian ini terhadap teori perencanaan berbasis komunikasi khususnya dalam kerangka proses kolaboratif adalah bahwa dialog tatap muka yang dijiwai oleh dialog otentik, bukan merupakan salah satu tahapan proses, tetapi mewarnai seluruh tahapan proses kolaboratif. Hal ini merupakan kontribusi penelitian ini terhadap proses kolaboratif dalam model Collaborative Governance yang dikembangkan oleh Ansell dan Gash (2007) serta memberikan kontribusi dalam menambah pengetahuan terhadap DIAD Network Theory dalam konteks proses kolaboratif.

\section{Daftar Pustaka}

Banfield, E.C. (1959) Ends and Means in Planning dalam Andreas Faludi (ed.) A Reader in Planning Theory (1973), pp 139-149., Pergamon Press Ltd, Oxford.

Beckman, Norman. (1964). The Planner as a Bureaucrat dalam Andreas Faludi (ed.) A Reader in Planning Theory (1973), pp 251-264., Pergamon Press Ltd, Oxford.

Creswell, John W. (1998). Qualitative Inquiry and Research Design; Choosing among Five Tradition, Sage Pub, California.

Creswell, John W. (2009). Reseach Design: Qualitative, Quantitative, and Mixed Methods Approaches, $3^{\text {rd }}$ ed., Sage Pub. Inc., California. 
Davidoff, Paul. (1965). Advocacy and Pluralism in Planning dalam Andreas Faludi (ed.) A Reader in Planning Theory (1973), pp. 277-296., Pergamon Press Ltd, Oxford.

De Roo, Gert. dan Porter, Geoff. (2007). Fuzzy Planning, The Role of Actors in a Fuzzy Governance Environment, Ashgate Publ. Limited, Hampshire.

Denzin, Norman K. dan Lincoln Yvonna S. (2009). Hand book of Qualitative Research, Dariyatno dkk. (penerjemah), Pustaka Pelajar, Yogyakarta.

Dyckman, John W. (1973). What makes Planner's Plan? dalam Andreas Faludi (ed.) A Reader in Planning Theory, pp. 243-250., Pergamon Press Ltd, Oxford.

Etzioni, Amitai. (1967). Mixed Scanning: A Third Appriach to Decision Making dalam Andreas Faludi (Ed.) A Reader in Planning Theory (1973), pp. 217-229., Pergamon Press Ltd, Oxford.

Faludi, Andreas (Ed.) A Reader in Planning Theory (1973). Pergamon Press Ltd, Oxford.

Forester, John. (1989). Planning in the Face of Power, The Univ. of California Press, California.

Forester, John. (2000). The Deliberative Practitioner Encouraging Participatory Planning Processes, $2^{\text {nd }}$ printing, Massachusetts Institute of Technology, London.

Friedmann, John. (1987). Planning in the Public Domain: From Knowledge to Action, Princeton Univ. Press, New Jersey.

Friedman, John. (2011). Insurgencies, Essay in Planning Theory. Routledge, London and New York.

Graham, S. dan Healey, P. (1999) : Relational Concepts of Space and Place: Issues for Planning Theory and Practice, European Planning Studies, 7(5), pp. 623-646.

Habermas, Jurgen. (2009). Teori Tindakan Komunikatif, Rasio dan Rasionalisasi Masyarakat, Nurhadi (Penerjemah), buku ke1, cetakan ke-3., Kreasi Wacana, Bantul.

Handayani, Suci. (2006). Merajut Harapan Menuju Perubahan, KOMPIP Solo, Solo.

Healey, Patsy. (2006). Collaborative Planning, Shaping Places in Fragmented Societies, $2^{\text {nd }}$ ed. Palgrave Macmillan, New York.

Innes, J.E. dan Booher, D.E. (2010). Beyond Collaboration Democratic Governance for a Resilient Society dalam Planning with Complex- ity, An Introduction to collaborative rationality or publicpolicy, pp 196-215., Routledge, Oxon.

Pemerintah Kota Surakarta. (2008). Empowering the Informal Sector (Street Vendors Management), Proceedings of Dubai International Award dengan kategori for Best Practices to Improve the Living Environment, Dubai.

Pemerintah Kota Surakarta. (2012). Surakarta dalam Angka 2011. Badan Pusat Statistik Kota Surakarta, Surakarta.

Subagyo, P. (2007). Memboyong 989 PKL, Badan Informasi dan Komunikasi Pemerintah Kota Surakarta, Surakarta.

Sufianti, E. (2013). The Role of Traditional Leadershipin Collaborative Processes: Javanese Leadership Case, dalam de Vries and Bouckaert (Ed.), Training for Leadership, pp121-134. Bruylant, Bruxelles.

Woltjer, Johan. (2000). Consensus Planning, The relevance of Communicative Planning Theory in Dutch Infrastructure Development, Ashgate Publ. Limited., Hampshire.

Yin, Robert K. (2009). Case Study Research, Design and Methods, $4^{\text {th }}$ ed., Aplied Social Research Methods, 5, Oaks, Sage Inc, California.

\section{Pustaka dari Situs Internet:}

Akadun. (2011). Revitalisasi Forum Musrenbang sebagai Wahana Parttisipasi Masyarakat dalam Perencanaan Pembangunan, MIMBAR, Jurnal Sosial dan Pembangunan, Vol. XXVII, No.2 (Desember 2011): hal. 183-191 'Terakreditasi' SK Dikti No. 64a/DIKTI/Kep/ 2010. http://ejournal.unisba.ac.id/index.php/ mimbar/article/view/327. Diunduh pada tanggal 8 September 2013

Ansell, C. dan Gash, A., (2007). Collaborative Governance in Theory and Practice, Journal of Publik Administration Research and Theory, 18:543-571., doi: 10.1093/jopart/mum032 First published, November 13, 2007. Diunduh pada tanggal 26 Oktober 2010.

Djoeffan, S. (2002). Strategi Partisipasi Masyarakat dalam Perencanaan Pembangunan di Indonesia. MIMBAR, Jurnal Sosial dan Pembangunan, 18, mar. <http:// ejournal.unisba.ac.id/index.php/mimbar/article/view/63>. Diunduh pada tanggal 18 Januari 2014.

Hardiman, F. B. (2008). Teori Dikursus dan Demokrasi: Peralihan dari Habermas ke dalam 
Filsafat Politik, Diskursus, vol 17 no 1, April 2008: 1-27., http://www.diskursus.com/ index.php/tema-diskursus/47-vol-7-no-1 april-2008/82-teori-diskursus-dan-demokrasiperalihan-habermas-ke-dalam-filsafat-politik. Diunduh pada tanggal 19 Nopember 2011.

Innes, J.E. (1996). Planning Through Consensus Building, a New View of Comprehensive Planning Ideal, Journal of American Planning Association Vol. 62 Issue 4. http://www.cipicu.ca/_CMS/Files/Innes, \%20Judith.pdf. Diunduh pada tanggal 13 Desember 2010.

Innes, J.E. (1998). Information in communicative planning, American Planning Association. Journal of the American Planning Association, 1:64., ABI/INFORM Global. http:// www.tandfonline.com/doi/pdf/10. Diunduh pada tanggal 27 Oktober 2011.

Innes, J.E. dan Booher, D.E. (2000). Collaborative Dialogue as a Policy Making Strategy, Institute of Urban and Regional Development UC Berkeley, IURD Working Paper, http:// escholarship.org/uc/item/8523r5zt. Diunduh pada tanggal 13 Desember 2010.

Innes, J.E. \& Booher, D.E. (2002). Network Power in Collaborative Planning, Journal of Planning
Education and Research, 21:221-236., Association of Collegiate Schools of Planning. http:/ /escholarship.org/uc/item/2mm270mp. Diunduh pada tanggal 30 Oktober 2011.

Sager, T. (2005). Communicative Planners as Naïve Mandarins of Neo-liberal State?, European Journal of Spatial Development, ISSN 1650-9544. http://www.nordregio.se/EJSD/. Diunduh pada Desember 2010.

Umar, Musni. (2011). Partisipasi Masyarakat Solo dan Demokrasi (Bagian ke IV), http:// musniumar.wordpress.com/2011/03/07/drmusni-umar-partisipasi-masyarakat-solo-dandemokrasi-bagian-ke-iv/. Diunduh pada tanggal 26 Desember 2011.

Widianingsih, Ida. (2005). Local Governance, Decentralization and Participatory Planning in Indonesia: Seeking a New Path to a Harmonious Society, Makalah dipresentasikan pada Workshop on Enlarging Citizen Participation and Increasing Local Autonomy in Achieving Societal Harmony Workshop, Network of AsiaPacific Schools and Institutes of Public Administration and Governance (NAPSIPAG) Annual Conference 2005., http://www.ehs.unu.edu/ file/get/9998. pdf. Diunduh pada tanggal 13 Desember 2011. 